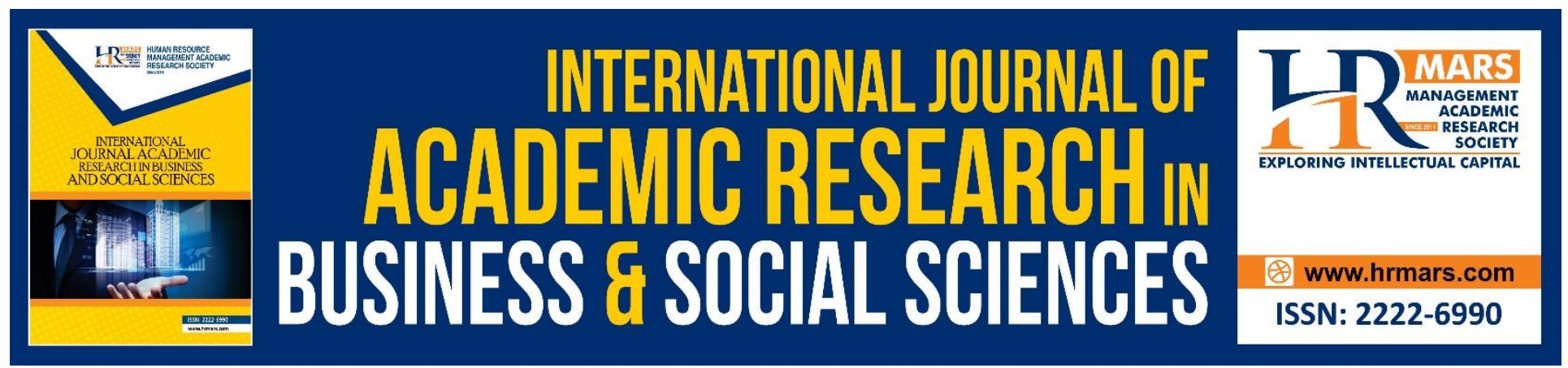

\title{
Determinants of Effectiveness of Performance Appraisal (EPA) for Academics in Nigerian Higher Education Institutions (HEls): A Pilot Study
}

Suleiman Abubakar Babagana, Norsiah Bt Mat, Hadziroh Binti Ibrahim

To Link this Article: http://dx.doi.org/10.6007/IJARBSS/v9-i3/5738

DOI: $\quad 10.6007 /$ IJARBSS/v9-i3/5738

Received: 12 Feb 2019, Revised: 27 Feb 2019, Accepted: 23 Mar 2019

Published Online: 27 March 2019

In-Text Citation: (Babagana, Mat, \& Ibrahim, 2019)

To Cite this Article: Babagana, S. A., Mat, N. B., \& Ibrahim, H. B. (2019). Determinants of Effectiveness of Performance Appraisal (EPA) for Academics in Nigerian Higher Education Institutions (HEls): A Pilot Study. International Journal of Academic Research in Business and Social Sciences, 9(3), 722-735.

Copyright: (C) 2019 The Author(s)

Published by Human Resource Management Academic Research Society (www.hrmars.com)

This article is published under the Creative Commons Attribution (CC BY 4.0) license. Anyone may reproduce, distribute, translate and create derivative works of this article (for both commercial and non-commercial purposes), subject to full attribution to the original publication and authors. The full terms of this license may be seen

at: http://creativecommons.org/licences/by/4.0/legalcode

Vol. 9, No. 3, 2019, Pg. 722 - 735

http://hrmars.com/index.php/pages/detail/IJARBSS

JOURNAL HOMEPAGE

Full Terms \& Conditions of access and use can be found at http://hrmars.com/index.php/pages/detail/publication-ethics 


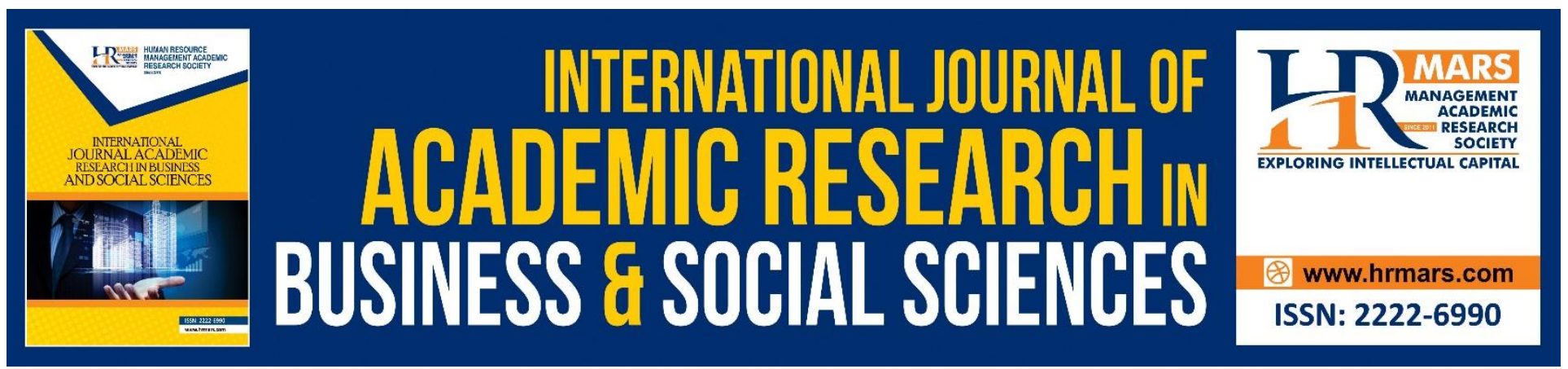

\title{
Determinants of Effectiveness of Performance Appraisal (EPA) for Academics in Nigerian Higher Education Institutions (HEIs): A Pilot Study
}

\author{
Suleiman Abubakar Babagana, Norsiah Bt Mat, Hadziroh Binti \\ Ibrahim
}

School of Business Management, Universiti Utara Malaysia, Sintok, Kedah, Malaysia

Corresponding Author Email: sbabagana@fptb.edu.ng

\begin{abstract}
Effective performance appraisal (EPA) is indispensable to organizations in establishing their accomplishments as well as improving employees' performance. Previous literature has indicated the impacts of organizational fairness, organizational politics, transactional leadership and employee's participation on performance appraisal (PA). The objective of this study is to confirm the validity and reliability of the research instruments in examining the relationships between organizational fairness, Politics, transactional leadership, and employees' participation on EPA among academics in Nigeria. A survey method was employed, and a total of 40 questionnaires set was distributed to respondents via convenience sampling. Results confirmed the validity and reliability of the instruments adapted.
\end{abstract}

Keywords: Effective Performance Appraisal, Organizational Fairness, Organizational Politics, Transactional Leadership, Employees Participation,

\section{Introduction}

Performance appraisal (PA) is one of the HRM policies that organizations endeavor to implement effectively. The effectiveness of performance appraisal (EPA) requires the support of top management by demonstrating commitment and translating organizational goals and objectives into individualized clear employee goals (Boice \& Kleiner, 1997). Executing PA with no well-defined objectives can have severe effects such as employee dissatisfaction, decreasing productivity and organizational commitment (Maley, 2013). Human resource management (HRM) literature indicated that PA is an area that HRM researchers and practitioners have focused interest on because of its observed impact on overall organizational effectiveness (Robbins \& Judge, 2009). Besides, it has also been reported that important positive job outcomes such as organizational commitment, job satisfaction, and work performance have an impact on the practice (Idowu, 2017; Kampkotter, 2016; Othman, 2014). Hence, effective EPA will reinforce the quality of the employee performance evaluation (Moradi, Mehraban \& Moeini, 2017), which might manifest on the overall employees' performance (Harrington \& Lee, 2015; Kampkotter, 2016). 
Extant literature (e.g, Atkins \& Wood, 2002; Banks \& Murphy, 1985; Schraeder, Becton \& Portis, 2007) have demonstrated the failure of PA systems in some organizations, and this warrants a holistic approach towards ensuring the practice of an EPA system (Ikramullah, Prooijen, Iqbal \& UIHassan, 2016;). Specifically, the problems militating against EPA have been reported in numerous studies. For instance, unfair judgement on a good performance in appraisals (Egginton, 2010; Getnet, Jebena, \& Tsegaye, 2014), organizational politics (Rosen, Kacmar, Harris, Gavin \& Hochwarter, 2017), as well as leadership (Tredrea, 2018) some of these issues. Similarly, the inability to consider the future by pursuing strategies that may produce better outcomes (Para-Gonzalez, Jimenez-Jimenez \& Marteinez-Lorente (2018), as well as less or non-employee participation (Roberts, 2003; Saad, 2014), makes the employees see the appraisal process as valueless and ineffective (Wright, 2004).

Arguably, prior studies, apart from developing frameworks, focused on certain predictors as determinants of EPA (e.g. Abbas, 2014; Christopher, Gregory, Alice, \& Elizabeth, 2017; Hemans \& Abena, 2011; Phin, 2015). Though, there are few studies that have investigated certain factors or variables to determine the EPA, yet, not much is known on how the variables for this study could establish EPA as the exploration of the area is still ongoing. Thus, the uniqueness of this study shall increase knowledge by developing a framework that will determine whether organizational fairness, organizational politics, and transactional leadership may establish EPA with the moderating role of employee participation in that regard.

Prior studies on EPA and its predictors adapted a variety of measures from different sources for the purpose of their research. This study has similarly adopted different measures from a variety of sources to achieve its aim. Accordingly, this paper presents the results of the pilot test concerning the determinants of EPA among academics in Nigerian HEls. The aim is to ascertain the reliability as well as the validity of the constructs in diverse settings and context at large before proceeding ahead to the main survey. This is desirable to confirm the content validity and internal consistency of the measures adapted. It is important because validity measures the degree to which an instrument is assessing what it ought to be measured, whereas reliability determines the extent to which an instrument is devoid of error and consistent among different measures of the scale (Sekaran \& Bougie, 2010).

\section{Literature Review}

\section{Performance Appraisal}

PA is an area that scholars and practitioners in HRM have focused interest because of its impacts on an organization's overall effectiveness (Robbins \& Judge, 2011). Scholars have been defined the concept in several ways. For instance, Giangreco, Carugati, Sebastiano and Al Tamimi (2012) defined it as a series of procedures carried out in organizations that centered on reviewing objective employees' responsibilities connected with mental attributes, as well as assessing expected performance against actual performance. It is also a procedure related to the annual evaluation of an individual's job performance aimed at improving individual and organizational performances. However, Bekele, Shigutu and Tensay, (2014) described it to mean an activity that measures employees' accomplishments and deficiencies in order to establish if a certain employee requires promotion or training based on assessed performance. Drawing from the above definitions, the concept can simply be described as a process meant to assess and develop employees' potentials 
within a stipulated period towards achieving organizational set objectives. Therefore it becomes imperative that organizations set and pursue PA policies that will support EPA system.

EPA plays a significant role towards evaluating employees' quality (Shin, 2011), as well as supporting managerial decisions in organizations on issues that could stimulate and boost employees' performance based on PA outcomes (Fletcher, 2001; Kampkotter, 2016). Moreover, it has been reported that PA impacts on organizational commitment and organizational performance (Armstrong-Stassen \& Schlosser, 2010; Williams, Christensen, LePere-Schloop \& Silk, 2015). This might perhaps justify why organizations in both the public and private sectors embrace the practice in order to achieve effectiveness and competitiveness (Armstrong \& Baron, 2005; Rusli \& Sopian, 2013). Therefore, addressing its ineffectiveness, as well as establishing the elements that will support its effectiveness becomes critical (Christopher et al, 2017; Idowu, 2017; Ikramullah et al, 2016; Iqbal, Akbar \& Budhwar, 2015; Longenecker \& Fink, 2013; Raja, 2016; Saad, 2014; Sharma \& Sharma, 2017). The standalone relationships between PA with elements such as; organizational fairness, organizational politics, transactional leadership, and employees' participation has been studied. However, bringing these elements in a framework to determine EPA will contribute towards further understanding the role they will play.

\section{Organizational Fairness}

Perceived fairness practices concerning issues such as employee PA are of paramount importance to organizations (Trivellas \& Kakkos, 2015). Thus, the trust employees have on the PA system fairness is very vital; otherwise, it may end up being of no value (Roberts, 2003). If, employees' perceptions on PA are seen as unfair, this might influence the benefits that could be derived from it, an employee's positive attitudes and performance may deteriorate instead of rising (Getnet, et al., 2014). It is observed that employees' views on all aspects of organizational fairness have an effect on their job performance throughout the PA process (Richter, Konig, Koppermann \& Schilling, 2016).

Extant literature has indicated that various types of organizational fairness have been established (Colquitt, LePine, Piccolo, Zapata, \& Rich, 2012). For instance, based on equity theory (Adams, 1963), it is argued that it consists of three dimensions which are; distributive fairness, procedural fairness and interactional fairness (interpersonal and informational) (Cheng, 2014; Collins \& Mossholder, 2017; Karkoulian, Assaker \& Hallak, 2016; Sharma, Sharma \& Agarwal, 2016). While some scholars (e.g, Trivellas \& Kakkos, 2015; VouBem, et al., 2016), argue that it has two dimensions which are distributive fairness and procedural fairness.

Distributive fairness signifies the degree to which outcomes of appraisal are allocated fairly (Saad \& Elshaer, 2017), as well as associated with the ratings of PA earned by employees (Abbas, 2014). However, Procedural fairness concerns decisions about the procedure used to establish outcomes (VouBem, et al, 2016), particularly the perceptions held by employees that procedures engaged by supervisors to evaluate their performances (Collins \& Mossholder, 2017; Colquitt et al., 2001; Salleh, Amin, Muda \& Halim, 2013). Interactional fairness is conversely, a social in nature, denoting supervisor-subordinate relations as well as the extent to which employees are treated in the PA process (Collins \& Mossholder, 2017; Greenberg, 2011; Salleh, et al, 2013). Scholars (e.g Collins \& Mossholder, 2017; Greenberg, 1993; Phin, 2015; Saad \& Elshaer, 2017) recognize the concept has two different and precise types or dimensions; interpersonal and informational. These types or 
dimensions have been reported as being particularly significant while studying relational phenomena (Collins \& Mossholder, 2017).

\section{Organizational Politics}

The enormity of the influence politics has on the appraisal of employee performance has been reported in Tziner, Latham, Price and Haccoun's (1996) study. Moreover, it was observed that the standing of politics regarding PA have been generally stressed in extant literature (Shah \& Hamid, 2016). Ahmad (2007) describes PA as comprising the use of various kinds of political influences and power with the intention to promote an internal political relationship among raters and ratees. However, Rosen, et al. (2017) contends that politics have an influence on the manner supervisors assess information while evaluating performance. It is further argued that once the main individual's interest was for employees' benefit, organizational politics may likely result in effective HR decisions (Saad \& Elshaer, 2017). But where employees probably recognize workplace politics as unbearable, withdrawal from the organization by indicating the intention to quit, turn out to be rampant (Ahmad \& Lemba, 2010).

\section{Leadership}

Northouse (2012) defined leadership as a manner that shows an individual's influence on a group of individuals to achieve common objectives. It is also explained as symbolizing the duty meant at realizing precise goals by exploiting human and material resources to accomplish a structured organizational interest (Ololube, 2013). Thus, effective leadership can be associated with the way that people and teams willingly shoulder responsibility for improving the appraisal process with skills development (Giri \& Gayathri (2018). Furthermore, Peretz and Fried (2012) argue that leaders should manage the challenging responsibility of PA as it affects the future of employees' performance.

Transactional leadership is a type of leadership style that is associated with two specific behaviors (Bass, 1985). First, contingent reward behavior and the second is "management by exception". This type of leadership style entails carefully observing for deviances, inaccuracies, and mistakes so as to ensure that corrective actions are applied as soon such are observed (Bass, Avolio, Jung \& Berson, 2003).

Research reported that transactional style leadership is positively connected to followers' commitment, satisfaction, and performance (Bycio, Hackett, \& Allen, 1995; Podsakoff, Todor, Grover, \& Huber, 1984).

\section{Employee Participation}

Employee participation is the participative way in which the efforts of the employees are utilized to increase their commitment to the accomplishments of an organization (Robbins \& Judge, 2009). In the PA process, employee participation is an essential element in achieving effectiveness (Saad, 2014). Besides, employee participation in decision making on HRM practices and policies enhances employee job satisfaction and performance (Bartram, Casimir, Stanton, Leggat, Bonias \& Cheng, 2009). Likewise, it has also been reported as significantly impacting on organizational effectiveness (Tahsildari \& Shahnaei, 2015), participation in management (Zhu, Xie, Warner \& Guo, 2015), and employees' commitment to the organization (Kirmizi \& Deniz, 2012). Moreover, employee participation in performance management system development is reported as linked to perceptions 
INTERNATIONAL JOURNAL OF ACADEMIC RESEARCH IN BUSINESS AND SOCIAL SCIENCES

Vol. 9, No. 3, March, 2019, E-ISSN: 2222-6990 @ 2019 HRMARS

held on the fairness of the appraisal system (Cawley, Keeping \& Levy, 1998; Colquitt, Conlon, Wesson, Porter, \& Ng, 2001).

\section{Methodology}

The study adapted a survey research design to examine the EPA among academics in a Nigerian higher education institution (HEI). This is a pilot study and is important in order to ascertain and confirm the reliability and validity of the research instrument (Flynn, Sakakibara, Schroeder, Bates, \& Flynn, 1990; Neuman, 2014). Thus, the main study shall integrate recommendations as well as implement them. Sample in this type of studies are generally not large (Fink, 2003). For instance, Lopez-Gamero, Molina-Azorín and Claver-Cortés (2009) and Plaza-Úbeda, de Burgos-Jiménez and Carmona-Moreno (2010) argue that for pilot study, the participants should range between five (5) to thirty (30) respondents. However, the number may be increased (Dillman, 2007). Thus, a range from twenty five (25) to seventy five (75) is suggested for pilot study (Babbie, 2008; Miller \& Salkind, 2002).

The essence of confirming reliability is to ascertain the degree to which measurements instrument are found to be with minimal or manageable errors (Zikmund, 2003). Hence, items or measures found to have high reliability suggests minimum likely error variance, so long as the analysis demonstrates high reliability value (Sekaran, 2003). Also, another justification for conducting a pilot study is to confirm questionnaire wordings are clear and relevance of the content. Based on the above reasons for conducting pilot study, in line with Forza's (2002) argument, the study was conducted in three different stages. Firstly, contact was established with experts in field of HRM as well as academics and the questionnaire were emailed to them for validation. Secondly, upon getting back the questionnaire from the experts, the instrument was revised to incorporate suggestions made. Thirdly, revised the questionnaire were self-administered to fifty (50) participants in one of the HEls within the scope of the study.

Closed-ended questionnaire was used and considered suitable as it enables reliable and easy generation of data for coding, tabulation and analysis (Dawson, 2007; Sekaran \& Bougie, 2010). Besides, it inspires the respondents' fast and easy choice of options in the questionnaire (Sekaran \& Bougie, 2010).

Furthermore, the items of the instrument were measured on seven-point (7) and five-point Likert (5) scales. This is because the use of multiple scales can help in avoiding common method bias (Crampton \& Wagner, 1994), and also generate better results (Sauro, 2010). Out of the 50 questionnaires distributed, 40 of them representing $80 \%$ were retuned and found to be correctly filled and were used for analysis.

Discussing on authenticating the validity of the instruments which is meant at establishing the extent to which the instrument measures are valid, literature indicated that validity of research instrument can be assessed through two ways which are; content validity and construct validity (Huck, 2004). Thus, content or face validity was conducted to confirm the validity of the items on the face to be certain that they are or will measure the intended constructs. This was achieved as mentioned above by the validation of experts. Similarly, reliability test was conducted. Even though there are diverse statistical techniques for testing reliability, Cronbach's alpha coefficient is reported as the most generally used technique by researchers with a threshold of 0.60 (Hussaini, Abubakar, \& Yusuf, 2018; Sekaran \& Bougie, 2010; 2016). Accordingly, SPSS v23 for Windows was employed to test the reliability of the 
measures.Babagana, S. A., Mat, N. B., \& Ibrahim, H. B. (2019). Determinants of Effectiveness of Performance Appraisal (EPA) for Academics in Nigerian Higher Education Institutions (HEls): A Pilot Study. International Journal of Academic Research in Business and Social Sciences, 9(3), 677-688.

\section{Result}

\section{Validity Test}

As mentioned in the preceding discussion, experts and academics in the field of HRM and a small sample of respondents were requested to provide comments and input on the appropriateness of the adapted measurement items of the constructs. Experts consulted comprise a Professor, Assistant Professor and a Senior Lecturer at Cardiff University, UK, UTB School of Business, Universiti Teknologi Brunei, and Umaru Aliyu Shinkafi Polytechnic, Sokoto, Nigeria respectively. Also, to ascertain the clarity and simplicity of the survey instruments, some lecturers in Nigeria were conferred with for their input. On the basis of these, certain items were rephrased appropriately to measure the constructs so as to be explicit to potential respondents.

\section{Reliability Test}

Drawing from the result of the reliability test, it is found that all the measures are above the accepted reliability values ranging from $\mathbf{0 . 6 5 7}$ to $\mathbf{0 . 8 6 0}$. This is consistent with the criterion that a Cronbach's alpha coefficient of 0.60 is deemed an average reliability, while a coefficient of 0.70 or higher signifies that the instrument has a high reliability standard (Sekaran \& Bougie, 2011). Table 4.1 demonstrates the summary of the reliability results. The results of the pilot test indicate that the Cronbach's alpha values for the respective constructs under examination are all above 0.60 . Therefore, in view of the established benchmark of 0.60 , conclusion can be drawn that all the constructs are reliable, consequently, no need to remove any item.

\section{Table 4.1:}

Reliability and Validity of Constructs $(n=40)$

\begin{tabular}{lll}
\hline Latent variables & $\begin{array}{l}\text { No. of } \\
\text { Indicators }\end{array}$ & Cronbach's alpha \\
\hline EPA & 3 & 0.790 \\
DF & 4 & 0.686 \\
PF & 7 & 0.765 \\
INTPF & 4 & 0.860 \\
INF & 5 & 0.777 \\
OP & 9 & 0.833 \\
TL & 4 & 0.657 \\
EP & 5 & 0.829 \\
\hline
\end{tabular}




\section{Demography of Respondents}

Table 4.2 presents descriptive analysis of the respondents. As shown in the table, most of the respondents were male representing $87.5 \%$, while $12.5 \%$ were female. Prior studies have reported same distribution pattern concerning respondents' gender. For instance, concerning gender distribution, this study reflects that of de-Lara and Tacoronte (2007) which reported most of teachers at a university were male. Also, the table shows that majority of the respondents fall in the category of 30-39 years closely followed by those within the range of $40-49$ years representing $32.5 \%$ and $30 \%$ respectively. Additionally, relating to level of education, the table shows a high percentage of the respondents are Master's Degree holders accounting $60 \%$ or 24 respondents and $7.5 \%$ or 3 as those with the least qualification possessing HND. Moving on to the years of working experience, the statistics revealed that $40 \%$ of the respondents served the institution for the period of 6-10 years and followed by $27 \%$ numbering 11 who served for $11-15$ years as presented in Table 4.2 . Finally, in terms of rank or position, the category of Senior Lecturers - Principal Lecturers accounted for $27.5 \%$ or 11 , while INS-PI and Chief Instructors categories accounted for 16 respondents from the sample representing $40 \%$.

Reflecting on the above statistical analysis, conclusion can also be drawn that, the various variables taken into consideration, the respondents in this study are deemed suitable towards achieving the objective of this study.

Table 4.2:

Demographic Characteristics of the Respondents

\begin{tabular}{lll}
\hline Item & Frequency & Percent \\
\hline Gender & 35 & 87.5 \\
Male & 5 & 12.5 \\
Female & & \\
Age & 7 & 17.5 \\
$18-29$ & 13 & 32.5 \\
$30-39$ & 12 & 30.0 \\
$40-49$ & 5 & 12.5 \\
$50-59$ & 3 & 7.5 \\
60 and above & & \\
Education & 3 & 7.5 \\
HND & 7 & 17.5 \\
Bachelors & 24 & 60.0 \\
Masters & 6 & 15.0 \\
PhD & & \\
Experience & 3 & 7.5 \\
$0-1$ & 4 & 10.0 \\
$2-5$ & 16 & 40.0 \\
6-10 & 6 & 15.0 \\
$11-15$ & 11 & 27.5 \\
16 \& Above & & \\
Rank & &
\end{tabular}




\begin{tabular}{lll} 
AL-LIII & 2 & 5.0 \\
LII-LI & 6 & 15.0 \\
SL-PL & 11 & 27.5 \\
CL & 4 & 10.0 \\
INS-PI & 8 & 20.0 \\
CI & 8 & 20.0 \\
TT-PT & 1 & 2.5 \\
\hline
\end{tabular}

\section{Conclusion}

Overall, this paper has achieved its objective by confirming the validity and reliability of the research instruments preparatory to the main study. Based on the results in this study, the pilot test results show that the Cronbach's alpha values for all the study constructs under examination exceed 0.60 . This indicates that the minimum acceptable threshold of 0.60 is met by all the constructs. Accordingly, there was no need to do away with any item.

\section{References}

Abbas, M. Z. (2014). Effectiveness of Performance Appraisal on Performance of Employees. Journal

of Business and Management, 2014(16), 6.

Ahmad, R., Lemba, C., \& Ismail, W. K. W. (2010). Performance Appraisal Politics and Employee Turnover Intention. Jurnal Kemanusiaan, 8(2).

Armstrong, M., \& Baron, A. (2005). Managing Performance: performance management in action. CIPD publishing.

Armstrong-Stassen, M., \& Schlosser, F. (2010). When Hospitals Provide HR Practices Tailored to Older Nurses, will older nurses stay? It may depend on their supervisor. Human Resource Management Journal, 20(4), 375-390.

Atkins, P.W. \& Wood, R.E. (2002), "Self-versus others' ratings as Predictors of Assessment Center Ratings: validation evidence for 360-degree feedback programs", Personnel Psychology, Vol. 55 No. 4, pp. 871-904.

Babbie, E. (2008). The basics of social research fourth edition. International student edition. Thomson Wadsworth, USA.

Banks, C.G. \& Murphy, K.R. (1985), "Toward Narrowing the Research-Practice gap in Performance Appraisal", Personnel Psychology, 38( 2), 335-345.

Bass, B. M. (1985). Leadership and Performance Beyond Expectations. Collier Macmillan.

Bass, B. M., Avolio, B. J., Jung, D. I., \& Berson, Y. (2003). Predicting Unit Performance by Assessing Transformational and Transactional Leadership. Journal of applied psychology, 88(2), 207.

Bekele, A. Z., Shigutu, A. D., \& Tensay, A. T. (2014). The Effect of Employees' Perception of Performance Appraisal on their work Outcomes. International Journal of Management and Commerce Innovations, 2(1), 136-173.

Boice, D. F., \& Kleiner, B. H. (1997). Designing Effective Performance Appraisal Systems. Work study, 46(6), 197-201.

Bycio, P., Hackett, R. D., \& Allen, J. S. (1995). Further Assessments of Bass's (1985) Conceptualization of Transactional and Transformational Leadership. Journal of Applied Psychology, 80, 468-478. 
INTERNATIONAL JOURNAL OF ACADEMIC RESEARCH IN BUSINESS AND SOCIAL SCIENCES Vol. 9, No. 3, March, 2019, E-ISSN: 2222-6990 @ 2019 HRMARS

Cawley, B. D., Keeping, L. M., \& Levy, P. E. (1998). Participation in the Performance Appraisal Process and Employee Reactions: A meta-analytic review of field investigations. Journal of applied psychology, 83(4), 615.

Cheng, S. Y. (2014). The Mediating role of Organizational Justice on the Relationship Between Administrative Performance Appraisal Practices and Organizational Commitment. The International Journal of Human Resource Management, 25(8), 1131-1148.

Christopher, K., Gregory, N., Alice, C., \& Elizabeth, N. M. (2017). Determinants of Effectiveness of Employee Performance Appraisal System in Institution of Higher Learning: A Survey of Public Universities in Nakuru County.

Collins, B. J., \& Mossholder, K. W. (2017). Fairness means more to some than others: Interactional fairness, job embeddedness, and discretionary work behaviors. Journal of Management, 43(2), 293318.

Colquitt, J. A., LePine, J. A., Piccolo, R. F., Zapata, C. P., \& Rich, B. L. (2012). Explaining the justiceperformance relationship: Trust as exchange deepener or trust as uncertainty reducer? Journal of applied psychology, 97(1), 1.

Crampton, S. M., \& Wagner, J. A. III. (1994). Percept-percept inflation in micro organizational research: An investigation of prevalence and effect. Journal of Applied Psychology, 79(1), 67-76

Dawson, C. (2007). Practical Research Methods: A user-friendly guide to mastering research techniques and projects (3rd ed., pp. 1-193). Oxford: How to Books Ltd.

Dillman, D. A. (2007). Mail and Internet Surveys: The tailored design method (2nd ed., Vol. 2, pp. 1542). New York: John Wiley \& Sons, Inc.

Egginton, B. E. (2010), "Introduction of Formal Performance Appraisal of Academic staff: the management challenges associated with effective implementation", Educational Management Administration \& Leadership, Vol. 38 No. 1, pp. 119-133

Fink, A. (2003). The survey handbook (Vol. 1). Thousand Oaks, CA: Sage.

Fletcher, C. (2001). Performance Appraisal and Management: The developing research agenda. Journal of Occupational and organizational Psychology, 74(4), 473-487.

Flynn, B. B., Sakakibara, S., Schroeder, R. G., Bates, K. A., \& Flynn, E. J. (1990). Empirical research methods in operations management. Journal of operations management, 9(2), 250-284.

Forza, C. (2002). Survey research in operations management: a process-based

perspective. International journal of operations \& production management, 22(2), 152-194.

Getnet, B., Jebena, T., \& Tsegaye, A. (2014). The Effect of Employee's Fairness Perception on Their Satisfaction towards the Performance Appraisal Practices (A Case Study of University of Gondar). International Journal of Management and Commerce Innovations, 2(1), 174-210.

Giangreco, A., Carugati, A., Sebastiano, A., \& Al Tamimi, H. (2012). War outside, ceasefire inside: An analysis of the performance appraisal system of a public hospital in a zone of conflict. Evaluation and program planning, 35(1), 161-170.

Giri, M. S., \& Gayathri, Y. (2018). An Empirical study on Employee Views and level of understating on Essentials of Performance Management System. Saudi Journal of Business and Management Studies (SJBMS) ISSN 2415-6663 (Print).

Greenberg, J. (2011). Organizational justice: The dynamics of fairness in the workplace. APA handbook of industrial and organizational psychology, 3, 271-327. 
INTERNATIONAL JOURNAL OF ACADEMIC RESEARCH IN BUSINESS AND SOCIAL SCIENCES Vol. 9, No. 3, March, 2019, E-ISSN: 222 2-6990 @ 2019 HRMARS

Greenberg, J., \& Cropanzano, R. (1993). The social side of fairness: Interpersonal and informational classes of organizational justice. Justice in the workplace: Approaching fairness in human resource management. Hillsdale, NJ: Lawrence Erlbaum Associates.

Harrington, J. R., \& Lee, J. H. (2015). What drives Perceived Fairness of Performance Appraisal? Exploring the effects of psychological contract fulfillment on employees' perceived fairness of performance appraisal in US federal agencies. Public Personnel Management, 44(2), 214-238.

Hemans, S., \& Abena, S. (2011). The Effectiveness of Performance Appraisal as a Tool for Enhancing Employee Performance in the Public Health Sector. Global Management Journal, 3.

Huck, S. W. (2004). Reading statistics and research (4th ed.). Boston, MA: Pearson.

Hussaini, U., Abubakar, A., \& Yusuf, M.-B. O. (2018). The effect of fraud risk management, risk culture, and performance of banking sector: Preliminary Analysis. International Journal of Academic Research in Accounting, Finance and Management Sciences, 8(3), 224-237.

Idowu, A. (2017). Effectiveness of Performance Appraisal System and its Effect on Employee Motivation. Nile Journal of Business and Economics, 3(5), 15-39.

Ikramullah, M., Van Prooijen, J. W., Iqbal, M. Z., \& Ul-Hassan, F. S. (2016). Effectiveness of performance appraisal: Developing a conceptual framework using competing values approach. Personnel Review, 45(2), 334-352.

Iqbal, M. Z., Akbar, S., \& Budhwar, P. (2015). Effectiveness of performance appraisal: An integrated framework. International Journal of Management Reviews, 17(4), 510-533.

Joseph, O. B. (2015). Effectiveness of Performance Appraisal as a Tool to Measure Employee Productivity in Organisations. Journal of Public Administration and Governance, 4(4), 135-148.

Kampkotter, P. (2016). Performance Appraisals and job Satisfaction. The International Journal of Human Resource Management, 28(5), 750-774.

Karkoulian, S., Assaker, G., \& Hallak, R. (2016). An empirical study of 360-degree feedback, organizational justice, and firm sustainability. Journal of business research, 69(5), 1862-1867.

Kırmızı, A., \& Deniz, O. (2012). The organisational commitment of IT professionals in private banks. International Journal of Logistics Systems and Management, 11(2), 175-197.

Longenecker, C. O., \& Fink, L. S. (2013). Creating Human-Resource Management Value in the Twenty-First Century: Seven Steps to Strategic HR. Human Resource Management International Digest, 21(2), 29-32.

Lopez-Gamero, M. D., Molina-Azorín, J. F., \& Claver-Cortés, E. (2009). The whole relationship between environmental variables and firm performance: Competitive advantage and firm resources as mediator variables. Journal of environmental management, 90(10), 3110-3121.

Maley, J. (2013). Hybrid purposes of performance appraisal in a crisis. Journal of Management Development, 32(10), 1093-1112.

Miller, D. C., \& Salkind, N. J. (2002). Handbook of research design and social measurement. Sage.

Moradi, T., Mehraban, M. A., \& Moeini, M. (2017). Comparison of the perceptions of managers and nursing staff toward performance appraisal. Iranian Journal of Nursing and Midwifery Research, 22(2), 128.

Neuman, W. L. (2014). Social research methods: Qualitative and quantitative approaches. Relevance of social research (Vol. 8).

Northouse, P. G. (2012). Introduction to leadership: Concepts and practice. (2nd ed., p. 4). SAGE Publications, Inc 
INTERNATIONAL JOURNAL OF ACADEMIC RESEARCH IN BUSINESS AND SOCIAL SCIENCES Vol. 9, No. 3, March, 2019, E-ISSN: 222 2-6990 @ 2019 HRMARS

Ololube, N. P. (2013). Educational Management, Planning and Supervision: Model for Effective Implementation. Owerri: SpringField Publishers.

Othman, N. (2014). Employee Performance Appraisal Satisfaction: The Case Evidence from Brunei's Civil Service.

Peretz, H., \& Fried, Y. (2012). National cultures, performance appraisal practices, and organizational absenteeism and turnover: A study across 21 countries. Journal of Applied Psychology, 97(2), 448459.

Phin, L. W. (2015). The Effectiveness of Performance Appraisal in the Private Education Industry in Malaysia. International Journal of Business and Information, 10(1), 95.

Plaza-Úbeda, J. A., de Burgos-Jiménez, J., \& Carmona-Moreno, E. (2010). Measuring stakeholder integration: knowledge, interaction and adaptational behavior dimensions. Journal of Business Ethics, 93(3), 419-442.

Podsakoff, P. M., Todor, W. D., Grover, R. A., \& Huber, V. L. (1984). Situational moderators of leader reward behavior and punishment behaviors: Fact or fiction? Organizational Behavior and Human Performance, 34, 21-63.

Raja, V. J. A (2016). A study on effectiveness of performance appraisal system in manufacturing industries in India. International Journal of Advanced Research in Management (IJARM, 7, (1)

Richter, M., König, C. J., Koppermann, C., \& Schilling, M. (2016). Displaying fairness while delivering bad news: Testing the effectiveness of organizational bad news training in the layoff context. Journal of Applied Psychology, 101(6), 779.

Robbins, S. P., \& Judge, T. A. (2009). Organizational Behavior. Pearson Prentice Hall. Robbins, S.P., \& Judge, T.A. (2011). Organizational behavior. (13th edn). Upper Saddle River:

Pearson.

Roberts, G. E. (2003). Employee performance appraisal system participation: A technique that works. Public personnel management, 32(1), 89-98.

Rosen, C. C., Kacmar, K. M., Harris, K. J., Gavin, M. B., \& Hochwarter, W. A. (2017). Workplace Politics and Performance Appraisal: A Two-Study, Multilevel Field Investigation. Journal of Leadership \& Organizational Studies, 24(1), 20-38.

Rusli, A. (2007). Employees appraisal: everything you have always wanted. Sarawak: Lee Ming Press Sdn. Bhd.

Rusli, A., \& Sopian, B. (2013). Issues and challenges in the Practice of Performance Appraisal Activities in the 21 centuries. International Journal of Education and Research, 1(4), 1-8.

Saad, S. K. (2014). Investigating the effectiveness of the performance appraisal process in the Egyptian tourism companies. Journal of Association of Arab Universities for Tourism and Hospitality, 11(2), 111-121.

Saad, S. K., \& Elshaer, I. A. (2017). Organizational Politics and Validity of Layoff Decisions: Mediating Role of Distributive Justice of Performance Appraisal. Journal of Hospitality Marketing \& Management, 1-24.

Salleh, M., Amin, A., Muda, S., \& Halim, M. A. S. A. (2013). Fairness of performance appraisal and organizational commitment. Asian Social Science, 9(2), 121.

Sauro, J. (2010). How many users do people actually test? Measuring Usability. Retrieved March 22, 2019, from http://www.measuringu.com/blog/actual-users.php. 
Schraeder, M., Becton, B.J. \& Portis, R. (2007), “A critical examination of performance appraisals an organization's friend or foe?", The Journal for Quality and Participation, 30(1), 20-25.

Sekaran, U. (2003). Research methods for business: A skill building approach (4th ed.). Hoboken, NJ: John Wiley and Sons.

Sekaran, U., \& Bougie, R. (2010). Research methods for business: A skill building approach. (5 $5^{\text {th }}$ ed.). John Wiley \& Sons.

Sekaran, U., \& Bougie, R. (2016). Research methods for business: A skill building approach. John Wiley \& Sons.

Shah, S. M. M., \& Hamid, K. B. A. (2016). Moderating Role of Performance Appraisal Politics on Transformational Leadership and Job Performance: A Proposed Framework. Journal for Studies in Management and Planning, 1(11), 676-683.

Sharma, A., \& Sharma, T. (2017). HR analytics and performance appraisal system: a conceptual framework for employee performance improvement. Management Research Review, 40(6).

Sharma, N. P., Sharma, T., \& Agarwal, M. N. (2016). Measuring employee perception of performance management system effectiveness: Conceptualization and scale development. Employee Relations, 38(2), 224-247.

Shin, J. C., Toutkoushian, R. K., \& Teichler, U. (Eds.). (2011). University rankings: Theoretical basis, methodology and impacts on global higher education (Vol. 3). Springer Science \& Business Media.

Tahsildari, A., \& Shahnaei, S. (2015). Enhancing Organizational Effectiveness by Performance Appraisal, Training, Employee Participation, and Job Definition. European Journal of Business and Management, 7(12), 56-63.

Trivellas, P., \& Kakkos, N. (2015). Understanding the impact of procedural justice, job characteristics, and resources on emotional exhaustion and its marketing-related implications. Anatolia, 26(1), 45-60.

Tziner, A., Latham, G. P., Price, B. S., \& Haccoun, R. (1996). Development and validation of a questionnaire for measuring perceived political considerations in performance appraisal. Journal of Organizational Behavior, 179-190.

VouBem, L., Kramer, S., \& Schäffer, U. (2016). Fairness perceptions of annual bonus payments: The effects of subjective performance measures and the achievement of bonus targets. Management Accounting Research, 30, 32-46.

Williams, B. N., Christensen, R. K., LePere-Schloop, M., \& Silk, P. D. (2015). Appraising the appraisal process: Manager and patrol officer perspectives. The Police Journal, 88(3), 231-250.

Wright, R. P. (2004). Mapping cognitions to better understand attitudinal and behavioral responses in appraisal research. Journal of Organizational Behavior: The International Journal of Industrial, Occupational and Organizational Psychology and Behavior, 25(3), 339-374.

Zhu, Y., Xie, Y., Warner, M., \& Guo, Y. (2015). Employee participation and the influence on job satisfaction of the 'new generation' of Chinese employees. The International Journal of Human Resource Management, 26(19), 2395-2411.

Zikmund, W. G. (2003), Business Research Methods (7th edition). South Western Pub. 